\title{
中山間地域における環境評価の総合化
}

\section{Generalization of Environmental Evaluation in Hilly and Mountainous Areas}

\author{
藤居良夫 \\ Yoshio Fujii \\ (信州大学工学部) \\ (Shinshu University)
}

\section{I はじめに}

今日の中山間地域においては, 過瑓化と高齢化 により晨林地の管理が困難となり，農林地の有す る多面的機能の低下が危惧されている。国土の健 全な保全のためにも，二の多面的機能が適切に発 揮され，さらに安全で快適な農村空間を創出する ための総合的な㻴境管理計画およびその管理技術 の開発が必要である。これまで, 農林地における 琵境保全機能を主とした多面的機能の評価手法が 提案・検討されてきた ( 4)。また，それに加えて

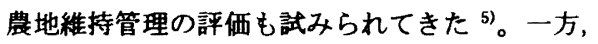
都市部における地域住民の生活皨境に対する意識 から捉えた堷指標に関する評価等 ${ }^{6,7}$ ) は検討さ れてきているが，中山間地域における住民意識に よる境境指標の棬築についてはまだ検討が進んで いない。

そこで本研究では，土地に起因する物理的な㻴 境と住民が意裁する境との両側面から，効果的 な中山間地域の保全管理対策を行うための 1 つの 基準を得るため, 中山間地域の土地がもつポテン シャルとしての多面的機能である国土保全機能の 評価と，住民の視点から生活の快適性を反映する 㻴境評価とを取り上げ，集落を単位として両評価 の総合化の手順を検討し，具体的な対象地域一の 適用を試みた生口。

\section{II 対象地域と分析手順}

本研究の事例として, 長野県 C 郡内のM町・ T 村・W村・N町の 4 町村を対象地域とした。この 対象地域は長野県の 中央部に位置し，典 型的な中山間地域の 1 つと考えることが できる。従来の研究 のほとんどは, 中山 間地域である 1 つの 町村のみを対象に議 論されているが, 本 研究では, 歴史的, 文化的, 地理的, ま た行政的にも関係す るC郡の 4 町村を取 り上げ，より広域的 な中山問地域で検討 した。対象地城の概 要を表 1 に，4 町村 の分布を図 1 に示す

(集落分布は図 4 参 照)。人口は全体的に 堿少傾向にあり，農 家人口に おける高 龄化率は 全集落平 均で約 $30 \%$ に上

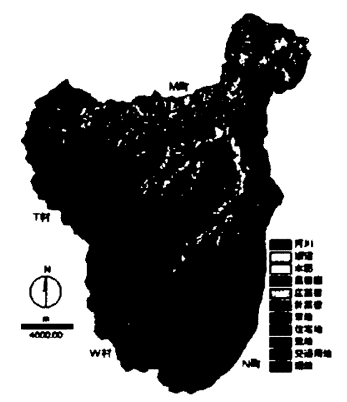

図 1 対象地城の分布 (求め大土地利用图上に示す)

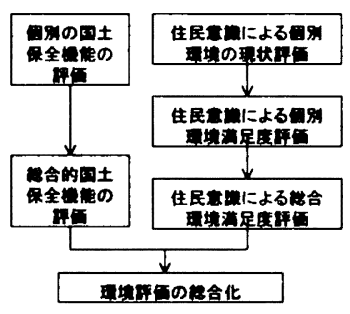

図 2 理境評価の総合 化の手順 表 1 C 郡 4 町村の概要 (H12.4)

\begin{tabular}{|c|c|c|c|c|c|}
\hline & MT & T村 & W村 & N町 & 4㽗㭘啫 \\
\hline 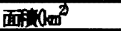 & 105.7 & 87.67 & 87.81 & 96,14 & 377.32 \\
\hline 世数(可) & 8861 & 1313 & 831 & 1753 & 12748 \\
\hline 䌊人口W & 25650 & 4257 & 2550 & 5266 & 37738 \\
\hline 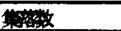 & 51 & 17 & 16 & 29 & 113 \\
\hline 年闻水 (m) & 1164 & 1513 & 1870 & 1528 & \\
\hline
\end{tabular}


り，耕作放㲤地率は全集落平均で約 15\%である。

国土保全機能の評価と住民意識による環境評価 から，対象地域における噮境評価の総合化を行う ための手順は欧のようにした（図2）。(1)地理情報 システムを活用して，対象地域における個別の国 土保全機能を評価し、これらを統合して総合的国 土保全機能の評価を行う, (2)対象地域において住 民意識調查を実施し，集落における個別揋境の現 状評価と, 住民の個別鏆境满足度および総合境境 满足度を求める, (3)上記の総合的国土保全機能評 価と住民意識による絰合璄境満足度評価とを組み 合わせて，集落を単位とした境評価の総合化を 図る。

\section{III 国土保全機能の評価}

\section{1 . 固別の国土保全機能評価}

中山間地域の国土資源は，農林業を営む場だけ でなく，自然墙境を維持するとともに，国土の保 全機能，あるいは境保全機能を有している。こ こでは, 対象地域が元来備えている国土保全機能 として土砂崩壊防止機能，洪水防止機能，土䘫浸 食防止機能, 大気浄化機能の 4 機能を取り上げた。

各機能の評価注 ${ }^{2)}$ は, 農業環境技術研究所 および旧国土庁・農水省が示している 1 3) 表 2 の評価式に従い，その演算には地理情 報システムを用いた。評価に必要なデータ は，表層地質・地形分類・土塔分布・植生 分布・傾斜角・土地利用の各データである が、これらのテータベース楆策には,「都道 府県士地分類基本調查」(1/50000 長野県), 第 3 回自然埭境保全調査 (旧境境庁), 数値 地図 $50 \mathrm{~m}$ メッシュ（標高）(国土地理院), およびランドサット TM データ（1995 年 5 月 18 日・Path108・Row35）を用いた。ただ し, 表層地 質・地形分 類・土烄分 布・植生分 布は表層地 質図・地形 分類図・土 䇾図・現存
植生図からデジタイザーにより求め, 傾斜角は数 値地図 50m メッシュを用いて算出し，土地利用は ランドサット TM データを用いて最尤法による土 地被覆分類を行って求めた。分析に当って, 全て のデータベースは国土地理院発行の地形図と同一

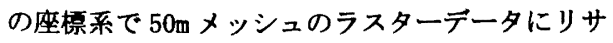
ンプリングして幾何補正を行った。

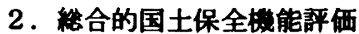

総合的国土保全機能評価を求めるため, 上記の 4 機能評価のデータを標準化して主成分分析を行 った。これより，第 1 主成分（奇与率 $95 \% ， 4$ 機 能の主成分負荷量は全て 0.9 以上）が 4 機能評価 を統合する指標になると判断して, 総合的国土保 全機能評価を表す指標と考えた（図 3 )。この評価 結果より，C郡 4 町村における総合的国土保全機 能評価が高い地域は対象地域南部の山間地に集中 している。また, 評価が低い地域はM町の中心部 やその北部など, 中山間地域のなかでも都市化が 進んでいる地域や標高差が大きい地域である。

また, 最終的な環境評価の総合化のため,この 総合的国土保全機能評価を集落別に平均して，そ れを 5 ランクに等分割化した（図 4 )。ランクが 1

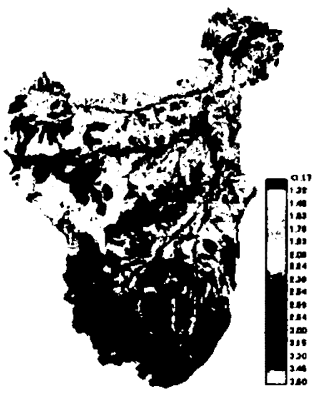

図 3 䍃合的国土保全 機能の評価

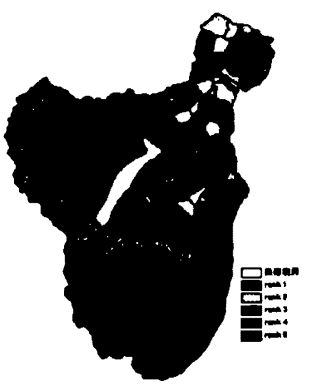

図 4 緿合的国土保全楼 能の集落別ランク分け

表 2 国土保全杫能の評価式

\begin{tabular}{|c|c|c|c|c|}
\hline 国王保全㥞能 & 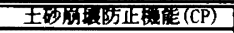 & 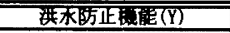 & 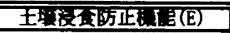 & 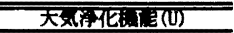 \\
\hline 瞳価式 & $\begin{array}{l}\mathrm{CP}=2 \mathrm{CP} 1+\mathrm{CP} 2+4 \mathrm{CP} 3 \\
+2(\mathrm{CP} 4+\mathrm{CP} 5+\mathrm{CP} 6+\mathrm{CP} 7)\end{array}$ & $\begin{aligned} Y=Y 1+2 Y 2+Y 3 \\
\\
+3 Y 4+2 Y 5+Y 6\end{aligned}$ & $\begin{aligned} \mathrm{E}= & \mathrm{E} 1 \times \mathrm{E} 2 \times \mathrm{E} 3 \\
& \times(\mathrm{E} 4+\mathrm{E} 5) \div 2 \times 100\end{aligned}$ & $\mathrm{U}=15.5 \times \mathrm{C} \times \mathrm{Pg} \times \mathrm{Lu}$ \\
\hline 客形目 & 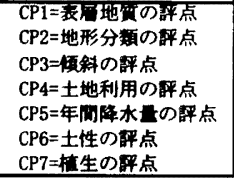 & 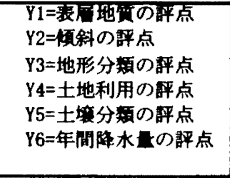 & 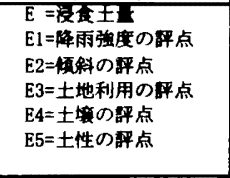 & 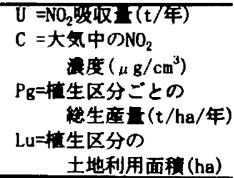 \\
\hline
\end{tabular}


〜 5 の順に評価は高くな

る。この結果から，対象 地域中部から北東部にか けての集落の評価が低く， 逆に対象地域南部の集落 の評価は全般的に高いこ とがわかる。

\section{IV 住民の渨境意識調查}

集落を単位とした嚗境評価を行う場合の重要な 要素が理境の快適性である。しかし，境境の快適 性については住民の主袹によるところが大きく， 境境基準等の一律の尺度での判断は困難である。 そこで猿境の快適性を評価するため，住民の聚境 意韵（亚境の現状および満足度）を調査した。こ こでは，棵境の快適性を表す個別塂境として，自

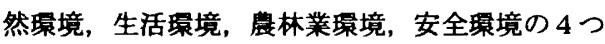
の大項目を設定した。具体的な評価の手順は次の ようである。(1)ンケート調査により個別程境の 現状および浢境の满足度に対するデータを収集す る，(2)重回㷌分析により，個別境境の满足度を個 別境境の現状から推定する評価式を檕筑する，(3) その評価式による推定值を説明変数として, 住民 意識による総合璄境満足度を表す回㷌式を求める。

\section{1.アンケート拥査の内容およひ方法}

対象地域である合計 113 集落の住民に対して， 自分達の住んでいる集落について，その個別最境 の現状と，謤境に対する满足度の意識調查を行っ た。アンケート調查票は各町村の区長を通じて各 集落に 20 部ずつ眍布した。回答者の選定にあたつ ては，その集落について精通している人物を各区 長に量んでもらった。調査票の配布概要は表 3 に 示すように, N町以外は回収率が $50 \%$ 近くあった。

調査内容については表 4 に示すように，個別㻴 境を表す 4 つの大項目（自然㻴境，生活環境，展 林業環境，安全㻓境）に対して，掫境の現状を表 すと考えられる合計 42 個の小項目を設けた。これ らの小項目に対して，「思う」，「やや思う」，「あま り思わない,「思わない」の 4 段階で回答しても らい,それぞれに 4〜1 の数值を与えて境境の現状 を数量化した。さらに，個別㻴境を表す 4 つの大
表 4 䚴査内容の小項目(非洒使用项目)

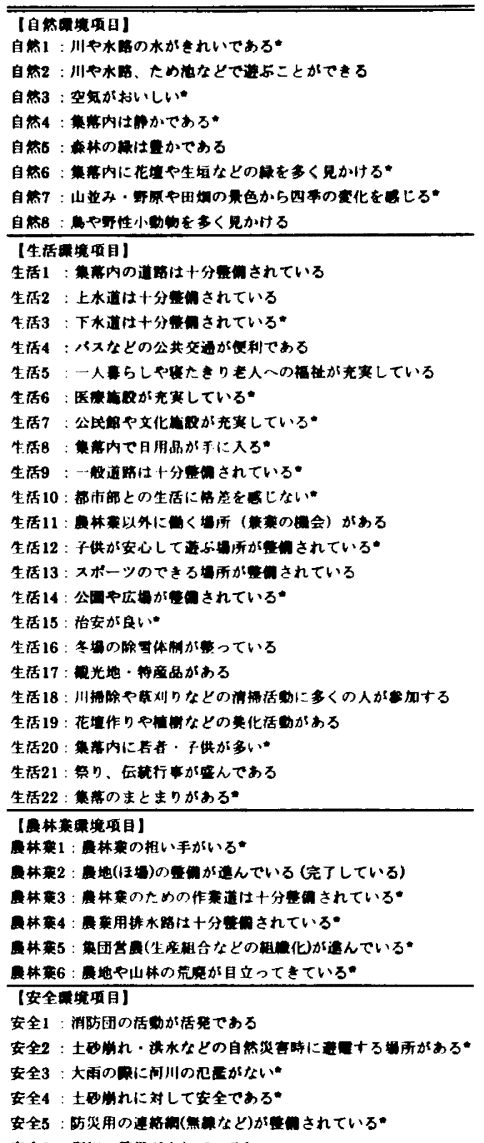

2. 住民

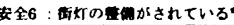

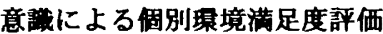

まず,個別舆境を表す 4 つの大項目 (自然境,

生活環境，農林業境境，安全噮境）に対する满足 度を説明する評価式を重回㷌モテルにより推定し た。この評価式に用いる説明変数は, 個別噮境の 現状を表す小項目(合計 42 個)の中から変数减少法 により絞り込んだ。また，推定の精度は重相関倸 数 $\mathrm{R}$, 分散分析の $\mathrm{F}$ 值と回㷌係数の有意性で判断 した注4)。

\section{（1）自然理境評価}

自然璪境については，表 4 に示す「自然 1」,「自 然 3」,「自然 4」,「自然6」,「自然 7〕の 5 小項目 
により，評価式を次のように構筑した。 [自然堁境砰価] =12.9+5.49[自然 1]+5.11[自然 3]+3.67[自 然 4]+6.31[自然 6]+3.40[自然 7]

( $\mathrm{R}=0.87, \mathrm{~F}$ 值・回淿係数: $5 \%$ 水㴖で有意)

この結果より，生活している集落内の緑の豊富 さ，川や水路のきれいさ等が自然環境の满足度に 強く影霨寸ることがわかる。

（2）生活理境評価

生活境については, 表 4 に示す「生活 3」,「生 活 6」, 「生活 7〕, 「生活 81, 「生活 9], 「生活 10 小,

「生活 12〕, 「生活 14」, 「生活 15], 「生活 20」, 「生 活 22」の 11 小項目により，評価式を炊のように 棬築した。

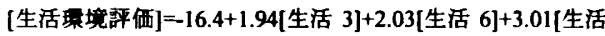
$7]+1.11$ 生活 8]+2.67[生活 9]+1.66[生活 10]+1.02[生活 12]+2.63[生活 14]+3.72[生活 15]+4.05[生活 20]+4.69[生活 22]

( $\mathrm{R}=0.87, \mathrm{~F}$ 值・回淿保数: $5 \%$ 水準で有意)

この結果から，集落内の奈囲気や人間関係等が 生活境境の满足度に強く影䇾することがわかる。

\section{（3）鹿林業棵境評価}

農林業震境については, 表 4に示す「農林業 1」, 「農林業 3」,「農林業 4」,「農林業 5」,「農林業 6」 の 5 小項目により,評価式を次のように構筑した。

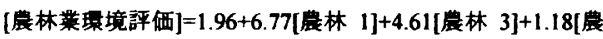
林 4]+4.19[晨林 5]+2.98[意林 6]

( $R=0.74, F$ 值・回㛿保数: $5 \%$ 水染で有意)

この結果から，農林業の担い手と生産基盤琹境 等が莀林業境境の满足度に強く影電することがわ かる。

\section{（4）安全棵境評価}

安全楒境については，表 4 に示す「安全 2」, 「安全 3」, 「安全 4」, ‘安全 5」, 「安全 6」 の 5 小項目により，評価式を次のように棈 筑した。

[安全境評価] $=15.6+3.90[$ 安全 2]+3.34[安全 $3]+10.89$ [安全 4]+3.17[安全 5]+3.38[安全 6]

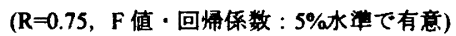

この結果から，自然災害に対しての安心 感等が安全境境の满足度に強く影期するこ とがわかる。

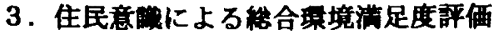

個別の謤境満足度評価を用いて総合環境满足度 評価を表す評価式を求めるため，上で求めた自然

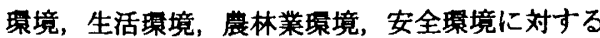
桭境满足度の推定値を用いて，重回㷌モデルによ り住民意識による総合境満足度評価を推定した 注5)。その結果，以下のような評価式が求められた。 住民意識による各環境の重要性を考察すると，総

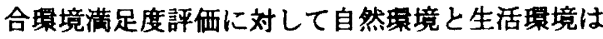
大きな影㽬力をもち，とりわけ生活㻴境が重要な 要素であると捉えられていることがわかる。

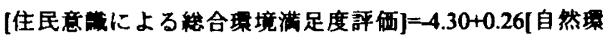
境]+0.70[生活果境]+0.07[宸林業果境]+0.16[安全望境]

( $\mathrm{R}=0.76, \mathrm{~F}$ 值 ・回㷌保数： $5 \%$ 水整で有意)

また，推定された個人単位での評価を集落単位 で平均した總合境境満足度評価の分布を図 5 に示 す。これより，最も評価の高い集落および最も評 価の低い集落は共にN町の集落である。また，最 終的な塨境評価の総合化のため, この総合環境満 足度評価を集落別に 5 ランクに等分割化した（図 6)。ランクが 1 ～5 の順に評価は高くなる。この 結果，対象地域中部の集落の評価が全般的に高い ことがわかる。

\section{V 中山間地域における器境評価の総合化}

効果的な中山間地域の保全管理対策を行うため の1つの基淮となる聚境評価を総合化するために， 5 ランクに分けた集落単位での総合的国土保全機 能評価と，5ランクに分けた集落単位での住民意

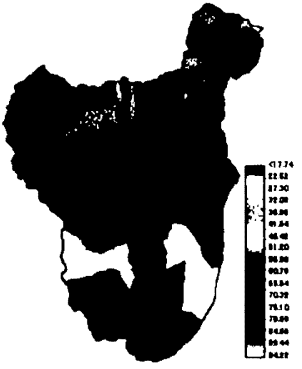

図 5 住民意域による集落 別の総合棵境灌足度評価

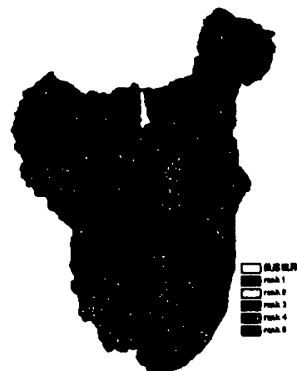

図 6 集落別の䍃合㻴境 满足度のランク分け 
識による総合環境満足度評価からクロスマトリッ クスを作成した（表 5)。5 ランクの評価は低（ラ ンク 1・2), 中 (ランク 3), 高（ランク 4・5）に 3 分類し，その組合せから 8 段階の順位 (A, B1, $\mathrm{B} 2, \mathrm{C}, \mathrm{D} 1, \mathrm{D} 2, \mathrm{E} 1, \mathrm{E} 2)$ を考えた。この順 位の集落ごとの分布を図 7 に示す。この評価の分 布から，M町では高い評価（順位A，B1，B2） の面積割合は $24 \%$ 程度で, 全体的に評価は低く， とくにM町東部には評価の高い集落と低い集落が 混在することがわかる。T村では高い評価（順位 A， B1，B2）の面積割合は $39 \%$ 程度で，全体的 に評価は中庸である。W村では高い評価(順位 $\mathrm{A}$, B 1，B2）の面積割合は $95 \%$ 程度で，全体的に評 価は高いが，とくにW村北東部には総合的国土保 全機能評の低い集落があることがわかる。N町で は高い評価（順位A，B1，B2）の面積割合は $83 \%$ 程度で, 全体的に評侮は高い。

この 8 段階の順位付けに対して，以下のような 評価ができる。

(1)順位Aに属する集落は，総合的国土保全機能評 価および住民意㯗による総合掫境満足度評価とも に高く,その集落のほとんどはW村と N町にあり， その面積割合はW村で 47\%，N町で $36 \%$ である。 (2)順位 B1 に属する集落は, 総合的国土保全機能 評価が高く，住民意識による総合噮境満足度評価 が中庯で，その集落の大部分はW村と N町にあり， その面積割合はW村で $54 \%$ ，N町で 44\%である。 (3)順位 B2 に属する集落は，総合的国土保全機能 評価が中庸で, 住民意識による総合㻴境満足度評 価が高く，その集落のほとんどは北部に位㯰し， その面糟割合はM町とT村でそれぞれ $32 \%$, N町 で 26\%である。

(4)順位Cに属する集落は, 総合的国土保全機能評 価および住民意識による総合環境満足度評価とも に中庸で，その集落のほとんどはM町と T村にあ り，その面積割合はM町で $56 \%$, T村で $36 \%$ であ る。

(5)順位D1 に属する集落は, 総合的国土保全機能 評価が高く，住民意識による総合環境満足度評価 が低く，その集落はN町の集落だけである。

(6)順位D2 に属する集落は, 総合的国土保全機能 評価が低く，住民意識による総合㻴境満足度評価 が高く，その集落は中部に分散し，その面積割合
は下村で 64\%である。

(7)順位E1 に属する集落は，総合的国土保全機能 評価が中屚で，住民意識による総合境境満足度評 価が低く，その集落はM町の一部のみである。 (8)順位E2 に属する集落は, 総合的国土保全機能 評価が低く，住民意識による総合境境満足度評価 が中庸で，その集落のほとんどはM町にあり，そ の面積割合はM町で 85\%である。以上のように, 境評価の総合化を 8 段階の順位で行った結果, 対象地域全体の集落数では順位 B2 と順位 Cに属 する集落がそれぞれ 32 と多く, 集落の面積割合で は順位Cに属する集落が $30 \%$, 順位A，B1，B2 に属する集落がそれぞれ $20 \%$ 程度であり，とくに 総合化した渨境評価が低い集落は対象地域北部の $\mathrm{M}$ 町東部と対象地域中部のW村, $\mathrm{N}$ 町の一部であ った。

\section{VI おわりに}

国土の均衡ある発展，ひいては地球璄境問題 への対処を踏まえて, 㻴境保全・国土保全の観 点より中山間地域を適切に管理していく必要性 があるとの認識から, 中山間地域における国土保 全機能

と住民 表 5 境境評価の總合化マトリックス

による

理境評 \begin{tabular}{l|l|l|}
\hline 低(rank 1.2) & 中(rank 3) & (rank 4.5) \\
\hline
\end{tabular}

価とを

取り上 げ,そ

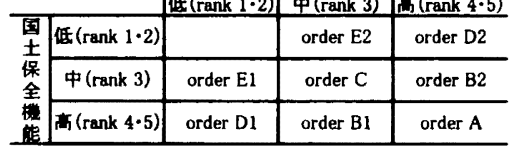

の両評価から集落 を単位とした憬境 評価の総合化の手 順を検討し，具体 的な対象地域への 適用を試みた。本 論での主眼は, 中 山間地域がもつ国 土保全に関するポ テンシャルに加え て, 各集落の環境 下で生活する住民

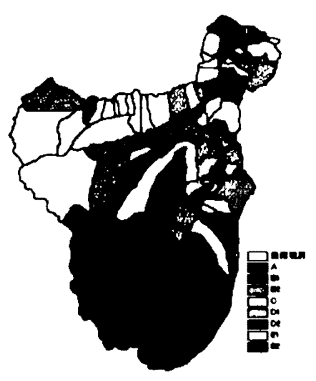

図 7 集落別の罢境評価 の䍃合化 
の視点から，快適性を反映した㻴境評価を総合化 することにある。これは中山間地域における渨 境の健全性を表し，効果的な中山間地域の保全 管理対策を行うための 1 つの基梀になると考え られる。このような㻴境評価の総合化の利用に関 しては，地域の境境管理計画の検討の䀢に，住民 による評価から集落の眇境を体系的に把握する ことや,この結果に基づいて住民と行政との連㩲 を促進すること、計画策定後の計画の進捗状況を 把暒すること,さらに境境の状䈍の变化に対して 適切に対応すること，またこれらの結果を計画に フィードバックすること等が考えられる。

今後の課題として, 検討する嘼境評価項目の見 直しや，住民意識に基づく瑻境評価データの収 集・加工方法の検討, 種々の噮境評価に対する適 切な統合化の方法等が举げられる。

槽注

注 1)ここでは，中山間地域の曼境保全および哝境管理を 検討する埸合，集落を最小単位とするのが通切である と考え，集落単位での襄境評価の總合化を検討した。 注 2)国土保全機能の評価の詳細や評点付けの根拠は引用 文茄 ${ }^{1 \sim 3)}$ を照のこと。

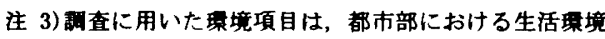

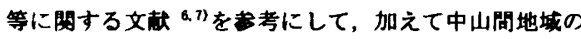
棵境管理・器境整備に関する多数の項目から，通切な項 目を整理統合して這んだ。ここでは，集落の個別瑟境の

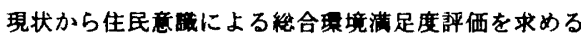
ことを主眼にしているため，個々の漫境項目を一括して 用いて，個々の棵境項目が㻴境满足度に及ほす影需の程 度を訊へた。また，紙面の都合で回答結果についての具 体的な記述は省略したが，回答者属性の概略は，性別て

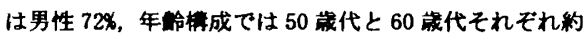

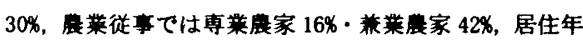

数では 20 年以上 $85 \%$ ある。

注 4) 分析結果の重相関係数は必ずしも大きいとは言えな いが，重回燸の精度を分散分析の F 值と回㛿係数の有意 性で判断した。

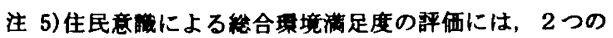
方法が考えられる。1つは，個別薪境の現状評価を表す データを説明変数として住民の総合虾境渵足度を推定 寸る評価式を直接求める方法であり，他の 1 つは, 先に 求めた個別㻴境の满足度の推定值を用いて住民の總合 㻴境消足度を推定する方法である。ここでは, 栏々な行 政領城での利用に対応できる聚境の項目を考芯して，後 者の方法をとった。

引用文散

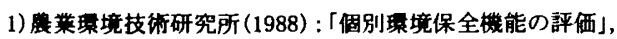

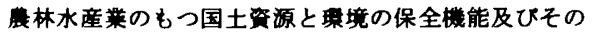
維持增進に関する繶合研究, pp. 45-63.

2) 国土庁計画・調壑局 (1992)：「立地特性を踏まえた国土

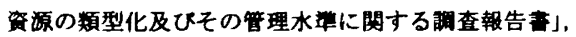
pp. 15-27.

3) Kato,Y, Yokohari,M and Brown,R.D.(1997):Integration and visualization of the ecological value of rural landscapes in maintaining the physical environment of Japan,Landscape and Uiban Planning 39, pp. 69-82.

4)山本腾利・加藤好武 (1999)：「聚境保全機能の評価から 見た鹿村ランドスケープの空間スケール」鹿村計画論文 集, 1, pp. 313-318.

5）藤居良夫(1999）：「国土保全機能から捉えた中山間地城 保全の一考察」㖘村計画諭文集，1，pp. 319-324.

6) 原科幸彦・田中充・内藤正明 (1990)：「住民䂓察にもと

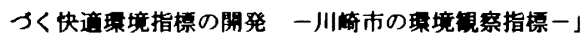
棵境科学会誌, 3(2), pp. 85-98.

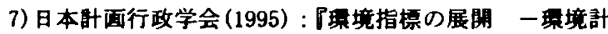
画への適用事例一』，学陽書房.

In this research, generalization of environmental evaluation was investigated in order to conserve hilly and mountainous areas as a case study of 4 towns and villages in C-county, Nagano prefecture. A synthetic evaluation expressing functions of national land conservation was constructed by means of geographic information system. A synthetic evaluation expressing degree of synthetic satisfaction to environment of settlement by residents' opinions was derived by the use of a questionnaire survey. Generalization of two synthetic evaluations as a unit of settlement was constructed. It is considered that this is an index expressing sound condition of hilly and mountainous areas. 